\title{
A Comparative Study of Customer Perceptions of Urban and Rural Bed and Breakfasts in Beijing: An Analysis of Online Reviews
}

\author{
Xin Zhang ${ }^{1,2}$, Jiaming Liu ${ }^{1,2, *}$, He Zhu ${ }^{1,2, *}$, Zongcai Huang ${ }^{3}$, Shuying Zhang ${ }^{3}$ and Ping Li ${ }^{4}$ \\ 1 Key Laboratory of Regional Sustainable Development Modeling, Institute of Geographic Sciences and \\ Natural Resources Research, Chinese Academy of Sciences, Beijing 100101, China; littlexin625@126.com \\ 2 College of Resources and Environment, University of Chinese Academy of Sciences, Beijing 100049, China \\ 3 State Key Laboratory of Resources and Environment Information System, Institute of Geographic Sciences \\ and Natural Resources Research, Chinese Academy of Sciences, Beijing 100101, China; \\ huang20110886@163.com (Z.H.); zhangshuying231@163.com (S.Z.) \\ 4 College of Recreation and Tourism, Beijing Sport University, Beijing 100084, China; liping@bsu.edu.cn \\ * Correspondence: liujm@igsnrr.ac.cn (J.L.); zhuhe@igsnrr.ac.cn (H.Z.)
}

check for updates

Citation: Zhang, X.; Liu, J.; Zhu, H.; Huang, Z.; Zhang, S.; Li, P. A Comparative Study of Customer Perceptions of Urban and Rural Bed and Breakfasts in Beijing: An Analysis of Online Reviews. Sustainability 2021, 13, 11303. https://doi.org/10.3390/ su132011303

Academic Editor: Lester Johnson

Received: 18 August 2021

Accepted: 6 October 2021

Published: 13 October 2021

Publisher's Note: MDPI stays neutral with regard to jurisdictional claims in published maps and institutional affiliations.

Copyright: (c) 2021 by the authors. Licensee MDPI, Basel, Switzerland. This article is an open access article distributed under the terms and conditions of the Creative Commons Attribution (CC BY) license (https:/ / creativecommons.org/licenses/by/ $4.0 /)$.

\begin{abstract}
The differences between urban and rural B\&Bs should be emphasized, which is critical for the sustainable development of the B\&B industry. This study identified and compared the topics that customers were concerned about for urban and rural B\&Bs in Beijing by analyzing 13,241 online reviews obtained from the website Ctrip. The results showed that customers focused on 10 common topics: "room", "location", "host", "experience", "surroundings", "facilities", "service", "design/style", "value", and "entertainment". However, the importance of each topic varied between urban and rural B\&Bs. Customers paid more attention to the room. Urban B\&B customers were more concerned about location. The convenience of urban B\&Bs was more prominent than that of rural B\&Bs, especially in terms of public transportation and commercial services. While rural $B \& B$ customers were more concerned about experience, service, design/style, and entertainment. In addition, the "host" is the most crucial and influential factor in the development of B\&Bs. This study made contributions to customer perceptions of $B \& B$ s from a comparative perspective and enriched the understanding of the characteristics of urban and rural B\&Bs. In the part of practice, this study might provide enlightenment for $\mathrm{B} \& \mathrm{~B}$ operators and local governments to take measures for B\&Bs sustainable development.
\end{abstract}

Keywords: comparative study; customer perceptions; bed and breakfasts; online reviews; Beijing

\section{Introduction}

Bed and breakfasts (B\&Bs), classified as a type of commercial home enterprise [1], have developed dramatically all over the world [2,3]. In some studies, the term B\&B is used interchangeably with other terms, such as homestay [4,5], bed and breakfast inn [6], guesthouse [7,8], and home-lodge [9]. Admittedly, the wide distribution of B\&Bs in urban and rural areas benefits to provide accommodation and leisure activities for tourists. Under different political, economic, and cultural backgrounds [10], urban and rural B\&Bs have presented differentiated characteristics in the process of development.

Previous studies on B\&Bs mainly focused on the marketing [11-13], management, and sustainable development of B\&Bs [5,14,15], as well as the consumer behavior [16], host-guest interaction [17], customer experience perceptions of B\&Bs $[4,18,19]$, and spatial distribution of B\&Bs [20-22]. The differences between urban and rural B\&Bs have not been well emphasized in existing studies. In many cases, B\&Bs are regarded as accommodation products produced in rural areas [23] or sustainable rural tourism products [24,25]. To date, less attention has been paid to urban B\&Bs than rural B\&Bs [26], and there is a lack of comparative studies of the two types of B\&Bs. The comparative understanding of B\&Bs in 
urban and rural areas is inadequate to support the theoretical and practical advancements in the B\&B industry.

Customers are users and experiencers of a product and service. During the process of consumption, customers form subjective feelings of a product or service [27,28], which can be regarded as customer perceptions. Exploring customer perceptions is beneficial to understanding the characteristics of products, what customers are concerned about, the factors that affect customer satisfaction and dissatisfaction, and the critical factors for industrial development. These findings can provide guidance for business management, marketing and sustainable development $[18,29,30]$. Related studies have been conducted on customer perceptions of the tourism and accommodation industry [31-35]. Some results: Fang et al. [32] studied Chinese B\&Bs in 10 tourist cities and extracted 7 indicators that customers care about most, including facilities and equipment, service, entertainment and culture, health and comfort, location, price, and catering. Sang et al. [36] extracted five $B \& B$ topics, including the external environment, basic service, personalized service, atmosphere, safety, and cost performance through a questionnaire. Some studies have shown that facilities and services are attributes that B\&Bs must offer and have indicated that providing attractive attributes such as free tours and free shuttle buses can not only differentiate B\&Bs from others but also improve tourist satisfaction [18]. In addition, existing studies have found significant differences in customers' perceptions of different types of accommodation [35]. Li et al. [37] investigated the differences between B\&Bs in Beijing and Taipei in terms of location selection, space creation, hosts' features, brand management, and the loyalty of tourists. Belarmino et al. [38] compared the dimensions of peer-to-peer accommodations and hotels and found that B\&B customers are more concerned about interactions with hosts, while hotel customers care more about the amenities. Overall, it is an important and reasonable way to explore B\&Bs from the perspective of customer perceptions. However, few studies have been conducted on customer perceptions of urban and rural B\&Bs, let alone the comparative studies of them.

Interviews and questionnaires have been the most common research methods of obtaining data $[18,29,30,39]$ in previous studies on customer perceptions. However, limited to the interviewees' patience and willingness, the results accuracy would decrease [40]. In addition, some possible factors may be overlooked in a questionnaire [41]. With the development of Internet technology and the boom of e-commerce platforms for accommodation, new data sources are being explored, such as online reviews. They contain rich information about customers' emotions based on personal evaluations of their experience and are more reliable than the standard information provided by the platform itself [30]. Because of their accessibility [42], large volume [43], and authenticity [44], online reviews have been widely used in research on customer perceptions in the tourism and accommodation industry $[41,43,45,46]$. However, current studies on analyzing customer perceptions of B\&Bs through online reviews are limited.

In China, with the development of domestic tourism, the B\&B industry is growing rapidly and has attracted more and more attention [20]. By the end of 2020, the total number of B\&Bs had reached 3 million, including 380,000 rural B\&Bs [47]. As a worldfamous tourist destination, Beijing is one of the most active cities in the development of B\&Bs in China. In 2020, Beijing invested RMB 12 billion in developing suburban tourism, with special emphasis on the construction of rural B\&Bs [48]. At present, the differences between urban and rural areas in Beijing still exist, which makes urban and rural B\&Bs development within different conditions. Under the background of high-quality tourism development and rural revitalization in China, B\&Bs should be continuously upgraded to meet customers' needs. Therefore, exploring the differences between urban and rural B\&Bs from customer perception is necessary, which can guide operators to improve the quality of services and to attract more customers. Moreover, the development of online travel platforms in China such as Ctrip can provide abundant online reviews for research.

Based on the above analysis, taking Beijing in China as the study area, this paper had two main objectives: (1) to identify the topics that customers are concerned about urban 
and rural B\&Bs by analyzing a large-scale sample of online reviews and (2) to compare the differences in customer perceptions towards urban and rural B\&Bs and explore the reasons in order to better understand the characteristics and general laws of the development of urban and rural B\&Bs. Furthermore, this study tried to make contributions on customer perceptions of $B \& B s$ from a comparative perspective. In the part of practice, this study might provide enlightenment for $B \& B$ operators and local governments to take measures for B\&Bs' sustainable development.

\section{Materials and Methods}

\subsection{Study Area}

This study selected Beijing as the case area (Figure 1). Beijing is the capital of the People's Republic of China and is also its political and cultural, international communication, and scientific and technological innovation center. There are 16 districts within its jurisdiction, including Dongcheng District, Xicheng District, Chaoyang District, Fengtai District, Shijingshan District, and Haidian District, along with 10 other districts. Beijing has an area of 16,410 square kilometers and recorded a permanent resident population of 21.893 million at the end of 2020; its gross domestic product (GDP) is RMB 3.61026 trillion.

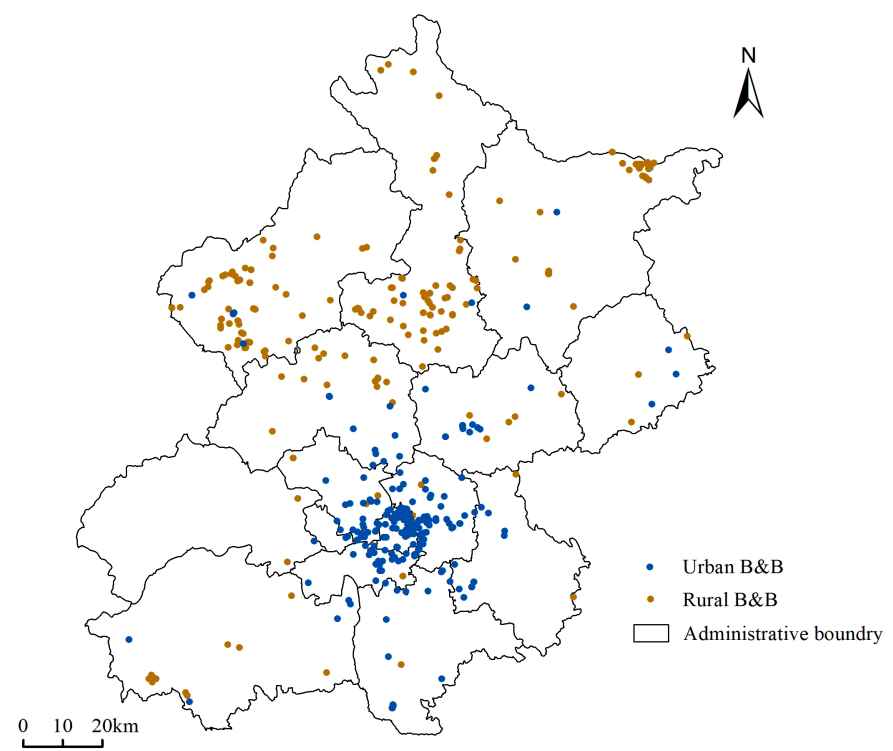

Figure 1. The case area and spatial distribution of urban and rural B\&Bs in Beijing.

The three main reasons for selecting Beijing as the study area are as follows. First, Beijing is a world-famous tourist city with many tourist attractions and attracts many tourists every year. In 2019, the total number of tourists reached 322 million [49]. The abundance of tourists has promoted the rapid development of $B \& B s$ in urban and rural areas. Second, the $B \& B$ industry in Beijing developed earlier and is more mature than those in other cities in China. According to one report [50], in 2020, Beijing was the city with the largest number of B\&Bs in China. At present, urban B\&Bs have become an essential supplement to traditional accommodations such as hotels and inns. Rural B\&Bs have also become popular tourist attractions. Many well-known B\&Bs brands have developed in suburban areas of Beijing, including "Hawthorn courtyard” (“山楂小院” in Chinese), “Grandma's home" (“姥姥家”), “Cuanshe” (“舉舍”), and “Shanlihanshe” (“山里寒舍”), which have attracted large numbers of visitors and vacationers. Third, there are many unique styles of B\&Bs in Beijing that can offer different experiences for customers. Due to Beijing's long history and urbanized development, the housing types in Beijing are diverse, including traditional housing (such as quadrangle courtyards) and stone houses, as well as modern housing, such as villas, apartments, farmyards, and bungalows. To meet customers' diverse 
needs for innovative accommodations and to attract tourists, B\&B hosts and investors have developed these housing types as B\&Bs.

\subsection{Study Design and Methods}

\subsubsection{Study Design}

To compare customers' perceptions of urban and rural B\&Bs based on online reviews, we designed an analysis framework (Figure 2), to present the process of the study. First, we collected online reviews and other B\&B-related information using Bazhuayu, a web crawler. Next, to build an effective database, we preprocessed the data that we obtained according to the following steps: cleaning, classifying, removing stop words, and replacing words. Word frequency analysis, statistical analysis, and social semantic network analysis were also carried out to obtain results.

Step1 Data Collection

Figure 2. The research framework for the study.

\subsubsection{Methods}

Text content analysis is a research method used to study textual data such as media messages and travel diaries and has been widely used in research on the tourism and hospitality industry [41,51]. It can be used to identify the key features researchers are concerned with, develop categories, and aggregate the content into discernible constructs [52]. Text mining can obtain both implicit and potential information from large-scale text [53]. In this study, we used the ROST Content Mining 6 (ROST CM6) tool, developed by Professor Yang Shen from the School of Information Management at Wuhan University, to analyze online reviews through the methods of word frequency analysis and social semantic network analysis.

In some studies, a word with a definite meaning is regarded as a thematic word [54]. Word frequency refers to the number of times that a word appears in the text. Furthermore, a high-frequency word is a word that appears more frequently than other words, and it can reflect the primary subject matter of the text. In this study, the purpose of extracting high-frequency words was to identify the main concerns that customers paid attention to and, in turn, to better understand customers' perceptions of urban and rural B\&Bs in Beijing. The steps were as follows. First, word segmentation was conducted by using the word segmentation module in ROST CM6 to create a new text document. Second, to obtain a list of high-frequency words, the new text document was analyzed with the word frequency analysis module of ROST CM6.

Social semantic network analysis is a sociological approach that reveals the structure and links between words in the form of nodes and lines, and it is a mathematical and visual analysis technique $[55,56]$. A node represents a word in the semantic network, and the larger the node, the more influential the word is. A line means there is a link between two words, and the thickness of a line indicates the strength of the connection. In this study, based on online reviews, we constructed social semantic network diagrams using ROST CM6 to compare influential thematic words and to analyze their structure [57]. This method has been applied previously in tourism, geography, psychology, and education 
research [57-60] to analyze the semantic association between words. Hence, it was a feasible way for this study to explain the relationships between thematic words.

\subsection{Data Collection}

All the online reviews were collected from the website Ctrip. Ctrip is the largest online travel agency in China [61] and offers multiple travel services, such as accommodation reservation and ticket reservation; it is one of the most influential accommodation reservation platforms in China. Statistically, it had more than 300 million registered users by the end of May 2018 [54]. To meet customers' needs for B\&Bs accommodations, Ctrip has specifically established a search channel (which is called “民宿客栈” in Chinese) containing a wealth of B\&B-related information. Customers can browse information on all B\&Bs online and reserve them easily. The platform also allows customers to comment on their accommodation experiences with text and pictures to express their true feelings. Many prior studies have used data obtained from Ctrip [61,62], which indicates that it was also reasonable for us to use the data on the website.

Given that the study area was Beijing, we crawled all available online reviews about B\&Bs in Beijing. The data collection took place in August 2020. We obtained a total of 15,074 online reviews, dated between 3 January 2016 and 21 August 2020 (Figure 3). We also downloaded some related information, including the time of comments and the name, location, style and latitude and longitude of each B\&B. As shown in Figure 2, we collected a smaller number of reviews between January 2020 and April 2020 because the home quarantine measures inhibited people's travel in Beijing during the 2019 COVID-19 (2019nCov) outbreak, and this measure reduced customer demand for B\&B accommodation. Although the number of comments decreased in those months, this did not affect the overall results.

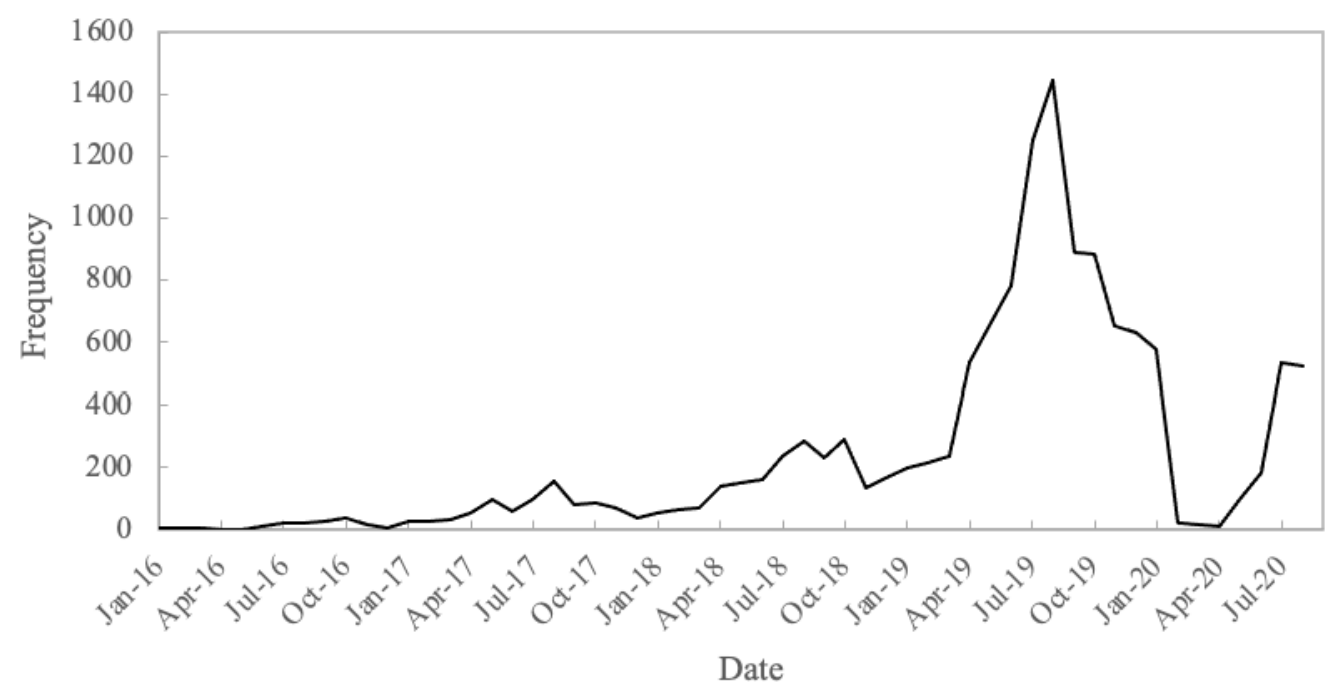

Figure 3. Frequency of online reviews.

\subsection{Data Preprocessing}

We preprocessed all the textual data we acquired from Ctrip by cleaning, classifying, and removing stop words and replacing words that had the same meaning with another word. First, to ensure the validity of the data analysis, it was essential to clean the data by deleting information related to non-B\&B accommodations such as hotels and hotel apartments; duplicate reviews were also removed because they might have led to statistical bias [54]. We were left with a total of 13,241 reviews of 618 B\&Bs. Second, based on the aims of the study, we divided the B\&Bs and their corresponding reviews into two groups based on their location. If B\&Bs were located in a village ("村 "), we classified them as rural B\&Bs. If B\&Bs were located in towns and urban areas, they were regarded as urban B\&Bs. We were left with 290 urban B\&Bs with 5507 reviews and 328 rural B\&Bs with 7734 
reviews (Table 1), which they were distributed in all of the districts of Beijing (Figure 3). Third, there are many meaningless words in online reviews, such as "there", "is", "a", and "an", which are of no substantive use for text content analysis. Therefore, to obtain effective textual data, the text mining tool ROST CM6 was used to delete these meaningless words, based on a stop word list provided by ROST CM6. This technique has also been used in many previous studies $[58,63,64]$. Finally, to ensure the accuracy of the data analysis, we used a common word to replace words with the same meaning.

Table 1. Summary of the sample.

\begin{tabular}{cccc}
\hline Type & Number of B\&Bs & Number of Reviews & Proportion \\
\hline Urban B\&Bs & 290 & 5507 & $41.59 \%$ \\
Rural B\&Bs & 328 & 7734 & $58.41 \%$ \\
Total & 618 & 13,241 & $100 \%$ \\
\hline
\end{tabular}

\section{Results}

\subsection{Topic Identification}

Using the ROST CM6 tool and the method of content analysis, we summarized 10 topics relating to customer perceptions of urban and rural B\&Bs in Beijing. Content analysis, as a qualitative method, can be used to transform unsystematic reviews into systematic qualitative data and can help researchers to classify thematic words and then identify seven topics according to a criterion [54] and with the participation of relevant experts. This method has been applied in previous research on topic classification $[65,66]$. In this study, we needed to extract topics from two groups of reviews, urban and rural $\mathrm{B} \& \mathrm{~B}$ reviews; the process of analysis was as follows. First, we obtained the top 500 highfrequency words and their frequencies for each group of reviews using the ROST CM6 tool. Second, words that had similar attributions were classified and then grouped into respective categories according to their interrelation and logical order [54] by three experts on the B\&B industry and tourism. Meanwhile, words that had no logical relationships with any other words were marked as "others" and were grouped together. Since these words could not be generalized to a theme, we then excluded the group of "others". Ultimately, 10 groups were obtained. Third, we invited each of the 3 experts to name each group in turn until they arrived at a consensus on the names of the 10 topics. Finally, we identified 10 common topics for urban and rural B\&Bs: "room", "location", "host", "experience", "surroundings", "facilities", "service", "design/style", "value", and "entertainment". The results are shown in Table 2 .

These topics represent customers' perceptions of their accommodation experience. The topics "room", "facilities", and "design/style" are related to the physical condition of B\&Bs. The topics "location" and "surroundings" indicate customer perceptions of the external environment of B\&Bs. "Service" and "entertainment" denote value-added services provided by B\&B operators for customers, including parking, cooking, cleaning, and some recreational activities. The remaining topics reflect the customers' evaluation of the host, accommodation experience, and the value of B\&Bs. Among them, "value" relates to the relationship between quality and price [35], a category in which words such as "worthy", "free", "cheap", and "benefits" indicate customers' evaluations of the value and prices of B\&Bs.

A topic contains related thematic words. To better illustrate the topic, we selected the top 10 thematic words for each topic based on the percentage of each thematic word and have listed these in Table 2. To save space, Table 3 only shows the topics "room" and "location" and their corresponding top 10 thematic words. For example, obviously, "convenience" (4.92\%), "subway" (2.16\%), and "transportation" (1.99\%) were the top three thematic words that customers mentioned most for urban B\&Bs for the topic "location", and they are related to accessibility and public transportation. 
Table 2. Extracted topics and the top 10 thematic words for urban and rural B\&Bs.

\begin{tabular}{|c|c|c|}
\hline \multirow{2}{*}{ Topic } & \multicolumn{2}{|c|}{ Top 10 Thematic Words } \\
\hline & Urban B\&B & Rural B\&B \\
\hline Room & $\begin{array}{l}\text { cleanliness, room, house, comfortable, tidy, } \\
\text { sanitation, cozy, quiet, indoor, kitchen }\end{array}$ & $\begin{array}{l}\text { room, cleanliness, comfortable, tidy, sanitation, } \\
\text { house, cozy, quiet, capacious, indoor }\end{array}$ \\
\hline Location & $\begin{array}{l}\text { convenience, subway, transportation, Beijing, } \\
\text { place, minute, travel, walking, distance, bus }\end{array}$ & $\begin{array}{c}\text { convenience, place, transportation, minute, travel, } \\
\text { drive, distance, easy to find, Beijing, Yanqing } \\
\text { District }\end{array}$ \\
\hline Host & $\begin{array}{l}\text { host, enthusiasm, sister, considerate, intimate, } \\
\text { attitude, prepare, beauty, aunt, eager }\end{array}$ & $\begin{array}{l}\text { host, enthusiasm, service, considerate, attitude, } \\
\text { intimate, attentively, earnest, patience, } \\
\text { circumspection }\end{array}$ \\
\hline Experience & $\begin{array}{c}\text { check-in, next time, satisfied, experience, suitable, } \\
\text { tourism, accommodation, night, grateful, highly } \\
\text { praise }\end{array}$ & $\begin{array}{c}\text { satisfaction, next time, check-in, experience, } \\
\text { suitable, night, happy, accommodation, have fun, } \\
\text { beautiful }\end{array}$ \\
\hline Surroundings & $\begin{array}{c}\text { circumjacent, environment, downstairs, } \\
\text { supermarket, Tian An Men, hospital, dining, } \\
\text { shopping, scenic area, mall }\end{array}$ & $\begin{array}{l}\text { environment, scenic area, Gubei Water Town, the } \\
\text { Great Wall, circumjacent, scenery, air, nearby, } \\
\text { surroundings, night scene }\end{array}$ \\
\hline Facilities & $\begin{array}{l}\text { well-equipped, facility, articles, refrigerator, } \\
\text { washing machine, supporting (facilities), } \\
\text { air-conditioning, heating, cooking utensil, toiletries }\end{array}$ & $\begin{array}{l}\text { well-equipped, facility, articles, air-conditioning, } \\
\text { supporting facilities, toiletries, furniture, } \\
\text { refrigerator, toy, television }\end{array}$ \\
\hline Service & $\begin{array}{l}\text { service, cooking, breakfast, cleaning, pack, } \\
\text { luggage, fruit, reception, parking, route }\end{array}$ & $\begin{array}{l}\text { service, shuttle service, housekeeper, breakfast, } \\
\text { barbecue, cooking, parking, park, cleaning, meal }\end{array}$ \\
\hline Design/Style & $\begin{array}{l}\text { community, decoration, style, layout, apartment, } \\
\text { design, small yard, characteristic, Hutong, villa }\end{array}$ & $\begin{array}{c}\text { small courtyard, decoration, style, in the yard, } \\
\text { layout, community, design, feature, villa, } \\
\text { apartment }\end{array}$ \\
\hline Value & $\begin{array}{l}\text { choice, hotel, cost performance, worthy, free, five } \\
\text { star, appropriate, cheap, benefits, consistent }\end{array}$ & $\begin{array}{l}\text { choice, hotel, cost performance, worthy, free, } \\
\text { benefits, reasonable, suitable, cheap, five-star }\end{array}$ \\
\hline Entertainment & $\begin{array}{l}\text { party, recreation, drinking tea, movie, mahjong, } \\
\text { billiards, chatting, leisure }\end{array}$ & $\begin{array}{l}\text { party, mahjong, holiday, chatting, playing, } \\
\text { recreation, relaxation, swing, billiards, parent-child } \\
\text { (activities) }\end{array}$ \\
\hline
\end{tabular}

Table 3. An example of two topics of thematic words.

\begin{tabular}{|c|c|c|c|c|c|c|c|}
\hline \multicolumn{4}{|c|}{ Topic: Room } & \multicolumn{4}{|c|}{ Topic: Location } \\
\hline \multicolumn{2}{|c|}{ Urban B\&B } & \multicolumn{2}{|c|}{ Rural B\&B } & \multicolumn{2}{|c|}{ Urban B\&B } & \multicolumn{2}{|c|}{ Rural B\&B } \\
\hline Cleanliness & $4.07 \%$ & Room & $4.59 \%$ & Convenience & $4.92 \%$ & Convenience & $2.22 \%$ \\
\hline Room & $4.05 \%$ & Cleanliness & $4.03 \%$ & Subway & $2.16 \%$ & Place & $1.09 \%$ \\
\hline House & $2.65 \%$ & Comfortable & $2.24 \%$ & Transportation & $1.99 \%$ & Transportation & $0.91 \%$ \\
\hline Comfortable & $2.13 \%$ & Tidy & $1.44 \%$ & Beijing & $1.62 \%$ & Minute & $0.48 \%$ \\
\hline Tidy & $1.41 \%$ & Sanitation & $1.25 \%$ & Place & $1.57 \%$ & Travel & $0.39 \%$ \\
\hline Sanitation & $1.12 \%$ & House & $1.22 \%$ & Minute & $0.70 \%$ & Drive & $0.31 \%$ \\
\hline Cozy & $0.92 \%$ & Cozy & $0.87 \%$ & Travel & $0.67 \%$ & Distance & $0.28 \%$ \\
\hline Quiet & $0.50 \%$ & Quiet & $0.53 \%$ & Walking & $0.57 \%$ & Easy to find & $0.23 \%$ \\
\hline Indoor & $0.46 \%$ & Capacious & $0.47 \%$ & Distance & $0.39 \%$ & Beijing & $0.17 \%$ \\
\hline Kitchen & $0.33 \%$ & Indoor & $0.45 \%$ & Bus & $0.36 \%$ & $\begin{array}{l}\text { Yanqing } \\
\text { District }\end{array}$ & $0.14 \%$ \\
\hline
\end{tabular}

\subsection{Comparison of Topics}

Although the topics determined for customers' perceptions of both urban and rural B\&Bs were common, the importance of each topic varied between urban and rural B\&Bs. To compare and show the difference, we calculated the percentages for all topics and drew a line chart as shown below (Figure 4). Figure 4 shows the relative difference of each topic for urban and rural B\&Bs. The $x$-axis represents the 10 topics, and the $y$-axis represents the percentages. The higher the percentages of a topic, the more attention customers paid to it. In general, the percentages of "room", "experience", and "host" were higher, and those for "design/style", "value", and "entertainment" were relatively low. This clearly 
shows that all customers were most concerned about the room. In reviews, customers were satisfied with the quality of rooms in both urban and rural B\&Bs, using words such as "cleanliness", "comfortable", "tidy", "sanitation", "cozy", and "quiet" to describe the rooms that they stayed in. This makes sense, since a room is the most basic requirement for accommodations; similarly to B\&B customers, rooms are also a key factor affecting hotel customer satisfaction [41].

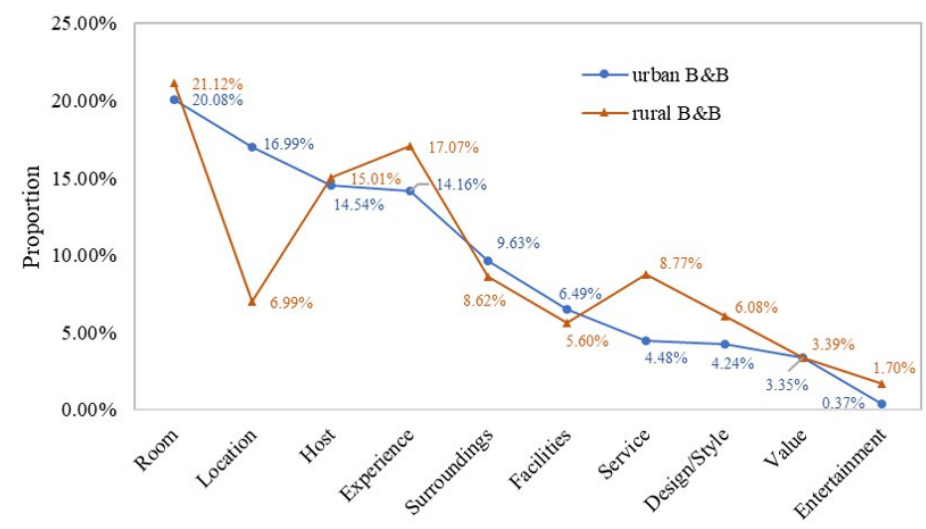

Figure 4. Comparison of the relative importance of the topics.

The percentages of the topics including "room", "host", "surroundings", "facilities", and "value" were almost equal for urban and rural B\&Bs, which suggests that customers paid similar attention to these topics for both types of B\&Bs. However, the level of concern about these topics varied. As shown in Figure 4, customers staying in urban and rural B\&Bs were most concerned about "room", with attention percentages of $20.08 \%$ and $21.12 \%$ recorded, respectively. However, they paid less attention to "value", with attention percentages of $0.37 \%$ and $1.70 \%$ recorded for urban and rural B\&Bs, respectively.

In addition, the importance of "location", "experience", "service", "design/style", and "entertainment" varied greatly with the type of B\&Bs. The percentage of "location" mentions for urban B\&Bs was significantly higher than that for rural B\&Bs, suggesting that urban $\mathrm{B} \& \mathrm{~B}$ customers referred to more location-related information than rural $\mathrm{B} \& \mathrm{~B}$ customers, which may be related to the transportation advantage of urban B\&Bs. However, the percentages of "experience", "service", "design/style", and "entertainment" for urban B\&Bs were relatively lower, indicating that customers staying in rural B\&Bs were concerned more about the accommodation experience, services, design/style of houses, and the entertainments provided by hosts.

\subsection{Comparison of Social Semantic Networks}

To further explore the most key thematic words and the links between them, we constructed two social semantic networks based on the top 200 high-frequency words from two groups of reviews using the Netdraw tool in ROST CM6. The two networks are shown in Figures 5 and 6, respectively. A node represents a thematic word. A bigger node indicates that it received more attention and has a broad association with other words in a network. The thickness of a connecting line represents the strength of the correlation between words [54]. The thicker the line, the stronger the connection between thematic words. 


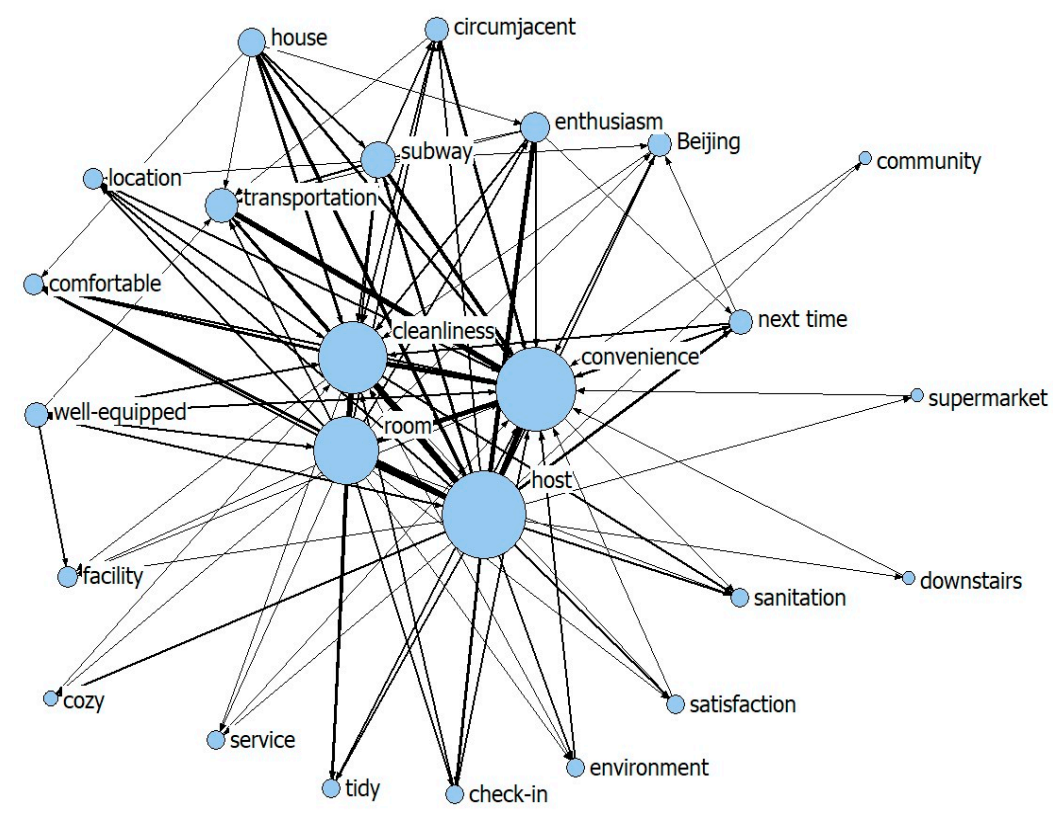

Figure 5. The semantic network graph of the customer perceptions of urban B\&Bs.

Comparing Figures 5 and 6, they have similar core words, including "host", "room", and "cleanliness", showing that these were important factors that customers considered when selecting a B\&B. The word "host" is the biggest node in the two networks, which indicates that it was the word most frequently mentioned by customers and was the most influential factor in the two groups of reviews. The emergence of this phenomenon may be related to the unique characteristics of $B \& B s$; that is, the host is the core factor for a $B \& B$ [26].The host-guest relationship distinguishes a B\&B from other forms of accommodation [23]. In contrast to hotels with professional attendants, $B \& B$ s are operated by the house owners, and B\&B operators need to provide services that meet their customers' needs, including check-in, shuttle services, cleaning, decoration, and other services. These frequent interactions between hosts and guests make the role of the host more prominent.

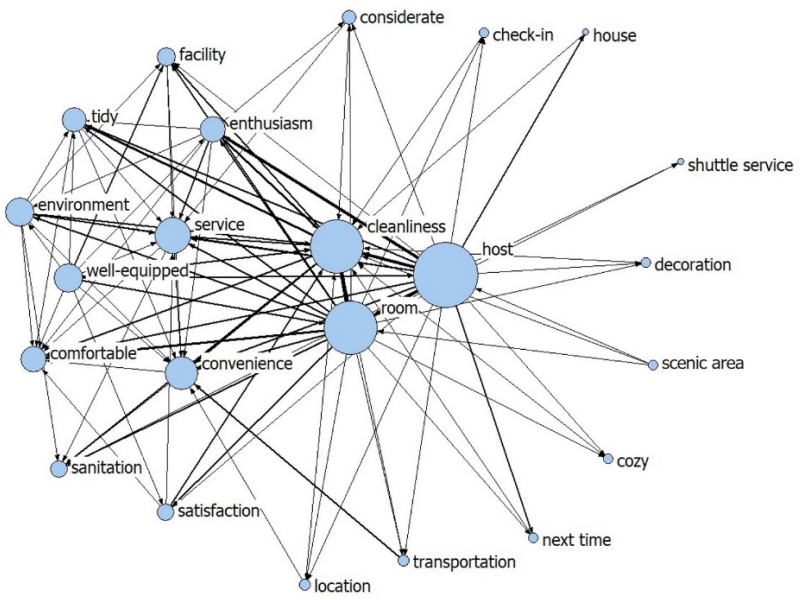

Figure 6. The semantic network graph of the customer perceptions of rural B\&Bs.

In addition, "room" and "cleanliness" are secondary common core nodes, which indicates that customers were concerned about having a clean room. This is similar to hotels, where cleanliness and the room were also critical factors for customers $[45,62]$. However, the thematic word "convenience", found in both network graphs, is more prominent in Figure 6, which indicates that the reviewers assessed urban B\&Bs to be more convenient than rural B\&Bs. As shown in Figure 6, the words associated with "convenience" included "transportation", "subway", "supermarket", "downstairs", "community", and so 
on, which shows that the reviewers found that urban B\&Bs had significant advantages in transportation and surrounding commercial services. Conversely, the convenience of rural B\&Bs was mentioned less and the size of the "convenience" node is smaller.

\section{Discussion}

First, by analyzing online reviews, this study extracted 10 topics: "room", "location", "host", "experience", "surroundings", "facilities", "service", "design/style", "value", and "entertainment". Some of them can also be found in previous studies in terms of customer perceptions on accommodation [29,34,35,67]. However, due to different analysis methods, study cases, and data, the results of customer perceptions of B\&Bs differ. In previous studies, the home or family-style atmosphere is identified to be an important factor for B\&Bs [34,68,69]. For example, Wang et al. [34] extracted six topics through content analysis of online comments: service, room facilities, location, cleanliness, home atmosphere, and value for money. However, through the comparison of relevant studies, we found that the attribute of home atmosphere for B\&Bs in Beijing was less mentioned from customers' reviews. Customers, especially domestic guests, are less likely to feel at home in B\&Bs in China [19]. This may be related to the commodification of private homes, which affects their authenticity [70]. As commodification develops, home elements are gradually replaced by more business-like elements [70], which slowly turns a home place ino a business enterprise [71]. However, compared to the atmosphere of a home, room-related information was mentioned most by customers, suggesting that the quality of a room is an important factor affecting customer experiences and satisfaction. In contrast, customers paid less attention to the value, especially the price, indicating that customers were not sensitive to the prices of either type of B\&B. To some extent, this echoes another study [17], which indicated that $\mathrm{B} \& \mathrm{Bs}$ in China are high-end accommodation products and a symbol of luxury, which makes customers more focused on social value than on functional value [17]. Therefore, the price is not an important consideration. However, this result does not apply entirely to all B\&Bs in Beijing, and thus the finding needs further validation. In addition, a possible reason for the finding is that customers reserved a $B \& B$ online and selected the price they could accept. Furthermore, the findings show that the entertainment services provided by Beijing B\&Bs are still the subsidiary products, rather than the core products. The tourism function of $B \& B$ s is not perfect. Today, providing accommodation is still the primary function of a $B \& B$. In fact, a $B \& B$ is seen as a transfer station for customers to other tourist attractions. Hence, it is essential to develop tourist attractions around $B \& B$ s in order to attract tourists and to in turn promote the development of B\&Bs.

Second, this study found that there were differences in the main concerns of urban and rural $B \& B$ customers. The customers of urban B\&Bs more often focused on the location. The results of statistical analysis showed that the customers of urban B\&Bs paid $16.99 \%$ attention to location, much higher than the $6.99 \%$ attention paid by the customers of rural $\mathrm{B} \& \mathrm{Bs}$. This finding indicates that location is a development and competitive advantage of urban B\&Bs. In general, urban areas have well-developed public transportation systems with many subway stations and bus stations. For urban tourists, taking public transportation is their main way to travel. To attract more customers, urban B\&Bs tend to be located in residential areas with convenient transportation options, which supports recent research [72]. However, in Beijing, public transportation in rural areas lags behind that in urban areas, which restricts the development of rural B\&Bs. Hence, rural B\&B customers mentioned the location less. However, they were more concerned about the experience, service, design/style, and entertainment of rural B\&Bs. In general, B\&Bs in rural areas are seen as tourist attractions or tourist destinations $[69,73]$. Customers staying in rural B\&Bs may value the aesthetic, leisure, vacation, and entertainment functions of rural $B \& B$ more than urban $B \& B$ customers. In addition, compared with urban areas, there is more space and land in rural areas for $B \& B$ operators to build different styles of housing and develop various entertainments, which can enrich customers' experiences greatly. Furthermore, 
customers who stay in rural areas that are not very convenient are especially likely to rely more on their hosts for personalized services.

Third, the study affirmed the central and critical role of B\&Bs by constructing social semantic networks. We found that the host is the key factor affecting the development of a $B \& B$ from the customer perspective. This also verifies the existing view that the host is the attribute most important in distinguishing a B\&B from a hotel [74]. In addition, the communication between hosts and customers is a critical part of the B\&B accommodation experience. In particular, customers who prefer to stay in B\&Bs value the communication with their hosts [74]; they want to be able to acquire information easily and solve problems effectively [75], as well as to learn about the local culture and experience the local lifestyle [5]. Hence, they need to built connections with their hosts. Furthermore, there is literature that shows that the emotional closeness between customers and hosts is the factor most important in business success [17], so hosts should also strengthen their relationships with their customers to improve customer satisfaction. Furthermore, we also found that the convenience of urban B\&Bs is more prominent than that of rural B\&Bs from the customer perspective, which also verifies the customers' view of the location superiority of urban B\&Bs.

\section{Conclusions and Implications}

Based on online reviews obtained from Ctrip, the study conducted a comparative analysis of customer perceptions of urban and rural B\&Bs in Beijing to reveal differences in topics of importance between these two B\&B types from the customer perspective. Using the method of content analysis and the ROST CM6 tool, we extracted 10 common topics that customers are concerned about for urban and rural B\&Bs: "room", "location", "host", "experience", "surroundings", "facilities", "service”, , design/style", "value", and "entertainment". However, there were differences in the importance of each topic between urban and rural B\&Bs. Among these topics, the topic of "room" received the highest attention. Urban B\&Bs showed greater advantages in location than rural B\&Bs. Meanwhile, rural B\&B customers were more concerned about the topics of "experience", "service", "design/style", and "entertainment", suggesting that rural B\&Bs outperform urban B\&Bs in these areas. Through the analysis of semantic networks, we then found that the "host" is the most influential common factor for the development of a B\&B, and the "room" and "cleanliness" are the second most common core nodes. In addition, the convenience of urban B\&Bs was more prominent than that of rural B\&Bs, especially in terms of public transportation and commercial services.

\subsection{Implications for Research}

This study has some important implications for academic research. First, the study provided comparative perspective for exploring customers' perceptions of urban and rural B\&Bs and then explored the reasons. These days, in China, a B\&B is not only an innovative type of accommodation but also a tourist attraction. B\&Bs located in urban and rural areas present different developmental characteristics. The study examined these differences from the perspective of customers and enriched understanding of the characteristics of urban and rural B\&Bs. In addition, the 10 topics that customers were concerned about provided a valuable reference for future research on selecting indicators to evaluate the B\&B accommodation. Second, the study provided an analytical framework to identify main topics from online reviews. Compared with questionnaires and interviews, online reviews contain rich information about customer accommodation experience and evaluation. However, extracting effective research supports from the massive information is hard. The framework presents a texting mining analysis process on identifying important topics from large-scale textual data, which may inspire related studies. 


\subsection{Implications for Practic}

The study extracted 10 topics from online reviews, which can help B\&B operators to identify what customers are concerned about and better understand customers' demands for B\&B accommodations. Additionally, by analyzing the differences in the topics between urban and rural $\mathrm{B} \& \mathrm{Bs}$, we were able to uncover the competitive advantages and shortages of these two types of $B \& B s$. Based on the findings, we will attempt to provide some targeted and effective measures that $B \& B$ operators and local governments can use to promote the sustainable development of B\&Bs in Beijing.

With the development of the social economy and the improvement of living standards, especially in the post-COVID-19 era, customers are more sensitive to their living environment and have higher quality demands for their accommodation products [76]; thus, $\mathrm{B} \& \mathrm{~B}$ operators should improve the quality of their rooms, which might include providing clean rooms, hygienic products, and sterilized furniture. Furthermore, B\&B operators should communicate with customers actively to understand their needs and solve their problems in a timely manner. By creating a harmonious and home-like atmosphere improves customer satisfaction and obtains positive reviews from customers. For urban B\&B operators, it is better to choose a site with better transportation and business services. The location advantage of urban B\&Bs in these two aspects should be further strengthened to improve competitiveness. Meanwhile, rural B\&B operators should integrate the surrounding resources to develop entertainments such as horse riding, fruit-picking, and handicraft making and organize a series of local festivals in order to attract customers and provide rich experiences for them. Moreover, rural B\&B operators should exploit local cultural resources while designing $B \& B$ s to highlight their unique styles, which helps to avoid the homogenization of competition between B\&Bs.

The local governments should take some effective measures to create a good development environment and conditions for B\&Bs in urban and rural areas. They should strengthen the supervision of urban B\&Bs to ensure the safety of facilities in rooms and the surrounding environment. Some beneficial policies on land, human resources, and capital should be made by governments to improve the development foundation of rural $B \& B s$. In addition, transportation is an important factor that customers consider when choosing a B\&B [26]. Hence, it is imperative for local government in Beijing to improve the public transportation conditions, especially in rural areas by planning bus routes and setting up proper bus stops to ensure that customers without cars can access rural B\&Bs. Moreover, local governments should set different standards for urban and rural B\&Bs to guide them towards sustainable development. In addition, a series of training courses should be arranged for all $B \& B$ operators to enable them to provide professional service to customers.

\subsection{Limitations and Future Research}

Some limitations and future research directions should be considered. First, we only collected and analyzed online reviews obtained from Ctrip. With the development of e-commerce, many professional online platforms for B\&Bs have emerged rapidly in China, such as Meituan, Tujia, and Xiaozhu. Future research should enrich our findings by verify the universality of the results by deriving more data from different online platforms. Second, in this study, we selected online reviews posted before August 2020, and did not consider the factor of time. In the future, customers' demands may change over time [77], and these changes may be reflected in their comments and reviews. Future studies should explore and compare the changes in customer perceptions of B\&Bs by analyzing long-term trends in online reviews. It is helpful for B\&B operators to understand customers' needs and make more effective strategies to enhance B\&Bs' competitive advantages.

Author Contributions: Conceptualization, J.L., H.Z. and X.Z.; methodology, H.Z. and X.Z.; software, H.Z. and P.L.; validation, S.Z. and H.Z.; formal analysis, X.Z.; investigation, X.Z.; resources, H.Z.; data curation, Z.H.; writing-original draft preparation, X.Z.; writing-review and editing, H.Z. and 
S.Z.; visualization, X.Z.; supervision, J.L.; project administration, H.Z. All authors have read and agreed to the published version of the manuscript.

Funding: This research was funded by the National Social Science Foundation of China (No.21ZDA07), the Strategic Priority Research Program of CAS (No.XDA23100302), and the National Natural Science Foundation of China (No. 41801139).

Institutional Review Board Statement: Not applicable.

Informed Consent Statement: Not applicable.

Data Availability Statement: The data supporting the reported results in the present study will be available on request from the corresponding author or the first author.

Conflicts of Interest: The authors declare no conflict of interest.

\section{References}

1. Lynch, P.A. Networking in the Homestay Sector. Serv. Ind. J. 2000, 20, 95-116. [CrossRef]

2. Kaufman, T.J.; Weaver, P.A. Marketing Efforts of Bed and Breakfast Operations: Do They Influence Success? J. Travel Tour. Mark. 1998, 7, 61-78. [CrossRef]

3. Lubetkin, M. Bed-and-breakfasts: Advertising and promotion. Cornell Hotel Restaur. Adm. Q. 1999, 40, 84-90. [CrossRef]

4. Mura, P. Perceptions of authenticity in a Malaysian homestay-A narrative analysis. Tour. Manag. 2015, 51, 225-233. [CrossRef]

5. Thanvisitthpon, N. Statistically Validated Component- and Indicator-Level Requirements for Sustainable Thai Homestay Businesses. Sustainability 2021, 13, 936. [CrossRef]

6. Lanier, P.; Berman, J. Bed-and-Breakfast inns: Come of age. Cornell Hotel Restaur. Adm. Q. 1993, 34, 15-23. [CrossRef]

7. Oliver, R.B.; Vazquez, F.S. Guesthouses and Inns in Spanish Southeast. The Decline of an Architectural Typology Linked to the Roads. IOP Conf. Ser. Mater. Sci. Eng. 2019, 471, 471. [CrossRef]

8. Zhao, Y. When guesthouse meets home: The time-space of rural gentrification in southwest China. Geoforum 2019, 100, 60-67. [CrossRef]

9. Agyeiwaah, E.; Akyeampong, O.; Amenumey, E.K. International tourists' motivations to choose homestay: Do their sociodemographics have any influence? Tour. Hosp. Res. 2013, 13, 16-26. [CrossRef]

10. Du, G.; Liu, M. A factor-based theoretical analysis of urban-rural relationship change. Prog. Geogr. 2021, 40, 1298-1309. [CrossRef]

11. Chen, L.-C.; Lin, S.-P.; Kuo, C.-M. Rural tourism: Marketing strategies for the bed and breakfast industry in Taiwan. Int. J. Hosp. Manag. 2013, 32, 278-286. [CrossRef]

12. Huang, L. Bed and breakfast industry adopting e-commerce strategies in e-service. Serv. Ind. J. 2008, 28, 633-648. [CrossRef]

13. Hudson, S.; Gilbert, D. The Internet and Small Hospitality Businesses: B\&B Marketing in Canada. J. Hosp. Leis. Mark. 2006, 14, 99-116. [CrossRef]

14. Chiu, C.-N. How can managerial efficiency be improved? Evidence from the bed and breakfast industry. Tour. Manag. Perspect. 2018, 27, 111-124. [CrossRef]

15. Pasanchay, K.; Schott, C. Community-based tourism homestays' capacity to advance the Sustainable Development Goals: A holistic sustainable livelihood perspective. Tour. Manag. Perspect. 2021, 37, 100784. [CrossRef]

16. Guttentag, D.; Smith, S.; Potwarka, L.; Havitz, M. Why Tourists Choose Airbnb: A Motivation-Based Segmentation Study. J. Travel Res. 2017, 57, 342-359. [CrossRef]

17. Zhang, X.; Tang, J. A Study of Emotional Solidarity in the Homestay Industry between Hosts and Tourists in the Post-Pandemic Era. Sustainability 2021, 13, 7458. [CrossRef]

18. Lin, C.-F.; Shiu, H.-J.; Wu, M.-Y. Exploring the Relationships Between Tourist Perceptions and the Service Quality of B\&Bs. J. Travel Tour. Mark. 2012, 29, 585-598. [CrossRef]

19. Zhang, Z.; Fu, R.J.C. Accommodation Experience in the Sharing Economy: A Comparative Study of Airbnb Online Reviews. Sustainability 2020, 12, 10500. [CrossRef]

20. Long, F.; Liu, J.; Zhang, S.; Yu, H.; Jiang, H. Development Characteristics and Evolution Mechanism of Homestay Agglomeration in Mogan Mountain, China. Sustainability 2018, 10, 2964. [CrossRef]

21. Gutiérrez, J.; García-Palomares, J.C.; Romanillos, G.; Salas-Olmedo, M.H. The eruption of Airbnb in tourist cities: Comparing spatial patterns of hotels and peer-to-peer accommodation in Barcelona. Tour. Manag. 2017, 62, 278-291. [CrossRef]

22. Quattrone, G.; Greatorex, A.; Quercia, D.; Capra, L.; Musolesi, M. Analyzing and predicting the spatial penetration of Airbnb in U.S. cities. EPJ Data Sci. 2018, 7, 31. [CrossRef]

23. Zhao, Y.; Chau, K.Y.; Shen, H.; Duan, X.; Huang, S. The influence of tourists' perceived value and demographic characteristics on the homestay industry: A study based on social stratification theory. J. Hosp. Tour. Manag. 2020, 45, 479-485. [CrossRef]

24. Walter, P.; Regmi, K.D.; Khanal, P.R. Host learning in community-based ecotourism in Nepal: The case of Sirubari and Ghalegaun homestays. Tour. Manag. Perspect. 2018, 26, 49-58. [CrossRef]

25. Janjua, Z.U.A.; Krishnapillai, G.; Rahman, M. A Systematic Literature Review of Rural Homestays and Sustainability in Tourism. SAGE Open 2021, 11, 11. [CrossRef] 
26. Mei, L.; Jiang, H. The spatial differentiation process, factors and trends of b\&b in Beijing based on Airbnb data. Econ. Geogr. 2021, 41, 213-222. [CrossRef]

27. Zeithaml, V.A. Consumer perceptions of price, quality, and value: A means-end model and synthesis of evidence. J. Mark. 1988, 52, 2-22. [CrossRef]

28. Long, F.; Zhu, H. Supporting the development of homestay tourism in the Yangtze River Delta: A study based on tourists' perceived value. J. Resour. Ecol. 2020, 11, 624-632.

29. Amoah, F.; Radder, L.; Eyk, M.V. Perceived experience value, satisfaction and behavioural intentions: A guesthouse experience. African J. Econ. Manag. Stud. 2016, 7, 419-433. [CrossRef]

30. Mohsin, A.; Lockyer, T. Customer perceptions of service quality in luxury hotels in New Delhi, India: An exploratory study. Int. J. Contemp. Hosp. Manag. 2010, 22, 160-173. [CrossRef]

31. Prayag, G.; Hall, C.M.; Wood, H. I feel good! Perceptions and emotional responses of bed \& breakfast providers in New Zealand toward trip advisor. J. Hosp. Mark. Manag. 2018, 27, 1-20. [CrossRef]

32. Fang, M.; Qu, Y. Research on the concern degree of online Bed \& Breakfast reputation evaluation based on text review. Areal Res. Dev. 2018, 37, 123-127. [CrossRef]

33. Zane, B. The \&B guest: A comprehensive view. Cornell Hotel. Restaur. Adm. Q. 1997, 38, 69-75. [CrossRef]

34. Wang, S.; Hung, K. Customer perceptions of critical success factors for guest houses. Int. J. Hosp. Manag. 2015, 48, 92-101. [CrossRef]

35. Sutherland, I.; Sim, Y.; Lee, S.K.; Byun, J.; Kiatkawsin, K. Topic Modeling of Online Accommodation Reviews via Latent Dirichlet Allocation. Sustainability 2020, 12, 1821. [CrossRef]

36. Sang, Z.; Feng, S.; Shi, P.; Dong, Y. Tourism bed and breakfast perception based on IPA theory: Importance, satisfaction and difference-A case study of EnShi prefecture of Hubei province. Resour. Dev. Mark. 2018, 34, 992-997. [CrossRef]

37. Li, Y.; Yu, W.; Bai, Y. Comparative research on B\&B and Taipei based on ratings on the Airbnb website. Chin. J. Manag. 2017, 14, 122-128.

38. Belarmino, A.; Whalen, E.; Koh, Y.; Bowen, J.T. Comparing guests' key attributes of peer-to-peer accommodations and hotels: Mixed-methods approach. Curr. Issues Tour. 2017, 22, 1-7. [CrossRef]

39. Chen, C.-M.; Chen, S.H.; Lee, H.T. The destination competitiveness of Kinmen's tourism industry: Exploring the interrelationships between tourist perceptions, service performance, customer satisfaction and sustainable tourism. J. Sustain. Tour. 2011, 19, 247-264. [CrossRef]

40. Hu, Y.-C.; Wang, J.-H.; Wang, R.-Y. Evaluating the Performance of Taiwan Homestay Using Analytic Network Process. Math. Probl. Eng. 2012, 2012, 1-24. [CrossRef]

41. Li, H.; Ye, Q.; Law, R. Determinants of Customer Satisfaction in the Hotel Industry: An Application of Online Review Analysis. Asia Pac. J. Tour. Res. 2013, 18, 784-802. [CrossRef]

42. Taecharungroj, V.; Mathayomchan, B. Analysing TripAdvisor reviews of tourist attractions in Phuket, Thailand. Tour. Manag. 2019, 75, 550-568. [CrossRef]

43. Guo, Y.; Barnes, S.J.; Jia, Q. Mining meaning from online ratings and reviews: Tourist satisfaction analysis using latent dirichlet allocation. Tour. Manag. 2017, 59, 467-483. [CrossRef]

44. Rhee, H.T.; Yang, S.-B. Does hotel attribute importance differ by hotel? Focusing on hotel star-classifications and customers' overall ratings. Comput. Hum. Behav. 2015, 50, 576-587. [CrossRef]

45. Xu, X.; Li, Y. The antecedents of customer satisfaction and dissatisfaction toward various types of hotels: A text mining approach. Int. J. Hosp. Manag. 2016, 55, 57-69. [CrossRef]

46. Hu, N.; Zhang, T.; Gao, B.; Bose, I. What do hotel customers complain about? Text analysis using structural topic model. Tour. Manag. 2019, 72, 417-426. [CrossRef]

47. China Tourism and Homestay Development Association: Research Report on Residential Accommodation Industry. Available online: https: / / www.donews.com/news/detail/4/3138936.html (accessed on 4 March 2021).

48. China Economic Net: Beijing: The Total Investment of Key Tourism Projects in Beijing Suburbs Will Reach 12 Billion Yuan in 2020. Available online: https:/ / baijiahao.baidu.com/s?id=1652047516677583517\&wfr=spider\&for=pc (accessed on 5 December 2019).

49. Beijing Municipal Bureau of Statistics; Survey Office of the National Bureau of Statistics in Beijing: Beijing 2019 Statistical Communique on National Economic and Social Development. Available online: http://tjj.beijing.gov.cn/tjsj_31433/tjgb_31445/ ndgb_31446/202003/t20200302_1673343.html (accessed on 2 March 2020).

50. Mo, M. IiMedia: Data Analysis of Homestay Industry: The Price of 8000 Homestays in Beijing in $2019-2020$ is More than 800 Yuan. Available online: https:/ / www.iimedia.cn/c1061/72974.html (accessed on 26 July 2020).

51. Stepchenkova, S.; Kirilenko, A.P.; Morrison, A.M. Facilitating Content Analysis in Tourism Research. J. Travel Res. 2008, 47, 454-469. [CrossRef]

52. Insch, G.S.; Moore, J.E.; Murphy, L.D. Content analysis in leadership research: Examples, procedures, and suggestions for future use. Leadersh. Q. 1997, 8, 1-25. [CrossRef]

53. Chen, Z.; Zhang, G. Study on the text mining and Chinese text mining framework. Inf. Sci. 2007, $25,46-51$.

54. Hou, Z.; Cui, F.; Meng, Y.; Lian, T.; Yu, C. Opinion mining from online travel reviews: A comparative analysis of Chinese major OTAs using semantic association analysis. Tour. Manag. 2019, 74, 276-289. [CrossRef] 
55. Shih, H.-Y. Network characteristics of drive tourism destinations: An application of network analysis in tourism. Tour. Manag. 2006, 27, 1029-1039. [CrossRef]

56. Park, D.; Kim, W.G.; Choi, S. Application of social media analytics in tourism crisis communication. Curr. Issues Tour. 2019, 22, 1810-1824. [CrossRef]

57. Tao, Y.; Zhang, F.; Shi, C.; Chen, Y. Social Media Data-Based Sentiment Analysis of Tourists' Air Quality Perceptions. Sustainability 2019, 11, 5070. [CrossRef]

58. Zhang, Y.; Shi, K.; Liu, J. Tourists' perception of the Grand Canal cultural heritage based on online travel notes. Areal Res. Dev. 2020, 39, 79-85.

59. Zou, Y.W.; Tian, F.J. View of tourism space image of Nanchang City on network virtual community. Resour. Sci. 2017, 39, 314-324.

60. Feng, X.; Zhang, D.; Rost, D.H. The research trend of German educational psychology in the past ten years: From the perspective of the educational realistic situation. J. Psychol. Sci. 2012, 35, 503-511.

61. Qi, M.; Li, X.; Zhu, E.; Shi, Y. Evaluation of perceived indoor environmental quality of five-star hotels in China: An application of online review analysis. Build. Environ. 2017, 111, 1-9. [CrossRef]

62. Wang, W.; Ying, S.; Lyu, J.; Qi, X. Perceived image study with online data from social media: The case of boutique hotels in China. Ind. Manag. Data Syst. 2019, 119, 950-967. [CrossRef]

63. Gao, J.; Han, D. A research on the image of historic urban blocks based on content analysis: A case study of Hengshan and Fuxing roads in Shanghai. Tour. Sci. 2014, 28, 1-12.

64. Li, P.; Chen, T.; Wang, F.; Wang, X. Urban tourism community image perception and differentiation based on online comments: A case study of Beijing. Geogr. Res. 2017, 36, 1106-1122.

65. Cheng, X.; Fu, S.; Sun, J.; Bilgihan, A.; Okumus, F. An investigation on online reviews in sharing economy driven hospitality platforms: A viewpoint of trust. Tour. Manag. 2019, 71, 366-377. [CrossRef]

66. Xiang, Z.; Du, Q.; Ma, Y.; Fan, W. A comparative analysis of major online review platforms: Implications for social media analytics in hospitality and tourism. Tour. Manag. 2017, 58, 51-65. [CrossRef]

67. Ding, K.; Choo, W.C.; Ng, K.Y.; Ng, S.I. Employing structural topic modelling to explore perceived service quality attributes in Airbnb accommodation. Int. J. Hosp. Manag. 2020, 91, 102676. [CrossRef]

68. Hsieh, Y.C.; Lin, Y.H. Bed and Breakfast operators' work and personal life balance: A cross-cultural comparison. Int. J. Hosp. Manag. 2010, 29, 576-581. [CrossRef]

69. Zhang, G.; Meng, Y. Progress of domestic and international research on B\&B tourism. Resour. Dev. Mark. 2017, 33, 503-507.

70. Ye, S.; Xiao, H.; Zhou, L. Commodification and perceived authenticity in commercial homes. Ann. Tour. Res. 2018, 71, 39-53. [CrossRef]

71. Sweeney, M.; Lynch, P.A. Classifying Commercial Home Hosts Based on their Relationships to the Home. Tour. Hosp. Plan. Dev. 2009, 6, 159-170. [CrossRef]

72. Xu, F.; Hu, M.; La, L.; Wang, J.; Huang, C. The influence of neighbourhood environment on Airbnb: A geographically weighed regression analysis. Tour. Geogr. 2019, 22, 192-209. [CrossRef]

73. Shi, H. The background, characteristic orientation and development strategy of homestay in China's rural tourism. Agric. Econ. 2017, 54-55.

74. Lee, C.K.H.; Tse, Y.K.; Zhang, M.; Ma, J. Analysing online reviews to investigate customer behaviour in the sharing economy: The case of Airbnb. Inf. Technol. People 2020, 33, 945-961. [CrossRef]

75. Priporas, C.-V.; Stylos, N.; Rahimi, R.; Vedanthachari, L.N. Unraveling the diverse nature of service quality in a sharing economy: A social exchange theory perspective of Airbnb accommodation. Int. J. Contemp. Hosp. Manag. 2017, 29, 2279-2301. [CrossRef]

76. Shen, S.; Wang, H.; Quan, Q.; Xu, J. Rurality and rural tourism development in China. Tour. Manag. Perspect. 2019, 30, 98-106. [CrossRef]

77. Berezina, K.; Bilgihan, A.; Cobanoglu, C.; Okumus, F. Understanding Satisfied and Dissatisfied Hotel Customers: Text Mining of Online Hotel Reviews. J. Hosp. Mark. Manag. 2016, 25, 1-24. [CrossRef] 